\title{
POLITYKA, EROTYKA, EGZOTYKA. KAMIENNE TABLICE PETELSKICH
}

Film Kamienne tablice Ewy i Czesława Petelskich (realizowany w 1983 r.) był droga produkcją, na którą w stanie wojennym mogli sobie pozwolić reżyserzy, którzy jednoznacznie poparli reżim. To ostatni film z ambicjami ideowymi, zrealizowany przez znany swego czasu reżyserski tandem, choć jednocześnie obraz miał wabić widza erotyką i egzotyką (akcja dzieje się w Indiach).

Wprowadzenie stanu wojennego przyniosło Petelskim (a właściwie głównie Petelskiemu, bowiem Petelska coraz mocniej odsuwała się w latach 80. w cień) na jednej szali doraźną korzyść i rekompensatę, na drugiej - długoterminowe wizerunkowe straty (dlatego po 1989 r. słuch właściwie po nich zaginą). Póki co, krótko po 13 grudnia 1981 r. reżyser oznajmiał: „Ze ściśniętym sercem dowiedzieliśmy się o wprowadzeniu stanu wojennego, z zapartym tchem słuchaliśmy dudnienia gasienic na ulicach naszych miast. Ale czy nie był to czas ostatni, by nie dopuścić do katastrofy najtragiczniejszej? Zrozumieć to musi każdy Polak. Bolesna to terapia, ale tak już jest, że lekarz zadaje czasem pacjentowi ból, by uchronić go od jeszcze większego, by uratować życie"1. Niedługo po tej i kilku innych deklaracjach 15 lutego 1982 r. został reaktywowany zespół filmowy „Iluzjon” (jako pierwszy po wprowadzeniu stanu wojennego), rozwiązany w okresie „karnawału Solidarności” z woli środowiska filmowego. Dwa miesiące później, 23 kwietnia odbyła się słynna kolaudacja filmu Przestuchanie Ryszarda Bugajskiego. Petelski, wraz kilkoma innymi kolaudantami (w tym Porębą i Waśkowskim) flekowali obraz, grzmiąc o antysocjalistycznej prowokacji. „Tu [w Przestuchaniu ] nie ma żadnych racji. Tu jest tylko i wyłącznie nienawiść. Nie do tego co było - do tego co jest"2. Reżyser mógł więc liczyć na wdzięczność władz. Środowiska opozycyjne nie pozostały dłużne - za poparcie wojskowego reżimu ogłosiły Czesława Petelskiego kolaborantem ${ }^{3}$. Mimo tego z głosem kolegów filmowców Petelski się liczył - dlatego też boleśnie przeżył środowiskowy ostracyzm w okresie Solidarności, w tym wspomniane odebranie ze-

ORCID: 0000-0002-1246-2275, DOI: 10.4467/23538724GS.20.061.13501

1 Cz. Petelski, Bolesna to terapia. Mówia przedstawiciele środowisk twórczych, „Dziennik Ludowy”, 31.12.1981, nr 292.

2 Præestuchanie, protokół z posiedzenia Komisji Kolaudacyjnej z dn. 23 kwietnia 1982 [w:] R. Bugajski, Przestuchanie, Warszawa 1990, s. 113.

3 Drugoobiegowe czasopismo „KOS” 1982, nr 2, s. 4. 
społu filmowego oraz całkowite zlekceważenie Bołdyna (1981), filmu, który sam odbierał jako rewizjonistyczny, w sztafażu opowieści wojennej krytykujący stalinowski kult jednostki. Przy czym krytyka systemu dokonana w Bołdynie była, jak na okres realizacji, łagodna i ostatecznie nie podważała ustrojowych pryncypiów (czego Petelski, zdaje się, nie dostrzegał).

Prace nad scenariuszem filmu Kamienne tablice rozpoczęły się jeszcze przed 13 grudnia 1981 r., wybór pierwowzoru wydawał się mocno przemyślany. Sytuacja Petelskiego była wtedy szczególna: pozbawienie zespołu filmowego i środowiskowy bojkot wzbudziły złość i chęć polemiki (ale też podświadome pragnienie rehabilitacji - stąd realizacja Bołdyna). Jednocześnie film nie mógł uderzać - jak kiedyś Baza ludz̧i umarbych - w ideowe pryncypia, status Petelskiego jako partyjnego reżysera był już utrwalony, także dla niego samego. W przypadku odrzucenia filmu przez środowisko filmowców i ludzi kultury (np. ze względów politycznych, pozaartystycznych) czy też przez krytyków (z powodów artystycznych) zawsze pozostawali widzowie. Box office mógł stać się ostatecznym usprawiedliwieniem i potwierdzeniem profesji reżysera, który potrafi robić filmy „dla ludzi”. Pełne sale kinowe mogły być dobrą wizerunkowa rekontra za odebranie zespołu filmowego. Wybór adaptowanej literatury nie był więc przypadkowy. Wydane w 1966 r., swego czasu bardzo poczytne Kamienne tablice Wojciecha Żukrowskiego wydawały się do tego celu idealne ${ }^{4}$. Lączyły historię i politykę z miłością i erotyką. Jak się później okaże, poszczególnych wątków tematycznych nie udało się połączyć i powstała gatunkowa hybryda. Chęć wrzucenia zbyt wielu grzybów do barszczu nie przyniosła efektu. Ale to wszystko było dopiero przed twórcami.

\section{Polityka}

W okresie po Sierpniu 1980 podjęto się realizacji filmów rewidujących oficjalną historię PRL, głównie okresu stalinowskiego, którego wizerunek był wcześniej reglamentowany (części z nich nie udało się skończyć lub skierować na ekrany przed wprowadzeniem stanu wojennego). Podobnie jak wiele filmów historycznych - co jest ich cechą strukturalna - także takie obrazy, jak Człowiek z marmuru (powstały jeszcze w 1976 r.), Dreszcze, Praypadek, Przestuchanie, Matka Królów czy Wielki bieg, odrywały się od historycznego kontekstu i nasuwały pytania alegoryczne: o zasadność systemu politycznego stworzonego na represyjnych i totalitarnych fundamentach. Petelscy chcieli więc z jednej strony wpasować się w jedną z dominujących ówcześnie tendencji tematycznych (dotknąć tematu tabu), z drugiej - polemizować z historiozoficznym defetyzmem zawartym w wymienionych opowieściach. Chcieli zrealizować film krytykujący błędy, ale nienegujący założeń systemu (czyli w kluczu typowego dla Października 56 hasła: „,socjalizm tak, wypaczenia nie”).

4 W. Żukrowski, Kamienne tablice, t. 1-2, wyd. 9, Warszawa 1977. 
By mocniej związać film z rodzimym kontekstem politycznym, Petelscy dokonali w scenariuszu zasadniczej zmiany w stosunku do pierwowzoru literackiego. Bohaterem ksiażki był Węgier, radca kulturalny ambasady węgierskiej w Indiach5; Petelscy protagonistą filmu uczynili Polaka, radcę polskiej ambasady w New Delhi, pomimo geograficznego oddalenia wciagniętego - emocjonalnie, ale i personalnie w miejscu pracy - w wir politycznych wydarzeń roku $1956 \mathrm{w}$ Polsce. Od razu dodajmy: impet rozliczenia z bolesną historią (niezależnie od przyjętych przez parę reżyserską ideowych aksjomatów) malał wraz z upływem czasu, co nie powinno dziwić, bowiem scenariusz pisano jeszcze przed 13 grudnia 1981 r., po czym został złożony do zespołu „Zodiak” Jerzego Hoffmana 4 stycznia 1982 r., a realizowany był ostatecznie (ponownie przez „Iluzjon”) w okresie stanu wojennego. Doraźna historia musiała wpłynąc na łagodzenie niektórych rozwiązań fabularnych. Nie wiadomo zreszta, czy gdyby nawet historia polityczna przełomu lat 1981/82 potoczyła się inaczej, niektóre zapisy scenariusza nie uległyby modyfikacji, miały bowiem mocno kontrowersyjny - nawet w okresie liberalizacji cenzury - charakter. Warto się im przyjrzeć.

Najważniejsza zmiana dokonała się w odniesieniu do kluczowych wydarzeń roku 1956 w Polsce. W scenariuszu ${ }^{6}$ najbardziej dramatycznym momentem historycznym - szczególnie dla bohatera, który pochodzi z Poznania i tam zostawił rodzinę - są wydarzenia Czerwca 1956. Również w filmie jest o nich trochę - ale niejako z drugiej ręki: Tokarski dowiaduje się o nich od Nagera, korespondenta AFP oraz z lokalnych relacji radiowych, w których pojawia się zarówno informacja o krwawych zamieszkach i szacowanych ofiarach, jak i słynne zdanie wypowiedziane przez Cyrankiewicza o ręce podniesionej na władzę, która zostanie odrąbana. Punktem kulminacyjnym tego historycznego wątku miało jednak być (w scenariuszu) unaocznienie tragedii - projekcja hinduskiej kroniki filmowej prezentującej uliczne zamieszki w Poznaniu. Opis tej partii jest bardzo dramatyczny:

I nagle Jan drgnął. Poznań. Na placu przed Zamkiem falujący tłum, ktoś wskakuje na ciężarówkę, przemawia. Szeroką ulicą idzie pochód, na czele tramwajarki z rozwiniętym biało-czerwonym sztandarem. Ręka Margit odnalazła dłoń Jana, pogładziła, a potem spoczęła mocnym uściskiem - jestem z tobą. Pochód dociera do gmachu Urzędu Bezpieczeństwa na Kochanowskiego, usta rozwarte do krzyku, z okien sypią się strzały. Kobieta ze sztandarem pada. Nie ma dźwięku, tylko podkład muzyczny, obraz drga, widać zdjęcia robione z ręki przez przypadkowego świadka. Popłoch, na jezdni zostają zabici i ranni. Łomocze karabin maszynowy. Zwłoki ładują na ciężarówkę, przez szpary w skrzyni leje się krew. Stara kobieta skulona pod murem płacze spazmatycznie (s. 120-121).

5 O politycznym odbiorze książki Żukrowskiego na Węgrzech okresu Kadara oraz reakcjach polskich zob. J. Tischler, Kamienne tablice obrasy, https://www.rp.pl/artykul/216168-Kamienne-tablice-obrazy.html (dostęp: 17.03.2021).

6 Archiwum Filmoteki Narodowej Instytutu Audiowizualnego (dalej: Archiwum FINA), S-25232, E. i Cz. Petelscy, Kamienne tablice - scenariusz, grudzień 1981; cytaty ze scenariusza przywołane w dalszej części tekstu pochodzą z tego maszynopisu. 
Ostatecznie w filmie radca Tokarski ogląda kronikę, w której pokazano „dwa Październiki”: węgierski (zamieszki, czołgi - ale bez informacji, że radzieckie - ofiary, krew) i polski (słynne ujęcia z placu Defilad: Gomułka wstępuje na trybunę, mówi o błędach; wiwatujący tłum). Parę godzin później bohater znów idzie do kina, aby obejrzeć kronikę po raz wtóry - Petelscy prezentują już tylko sceny węgierskie. Tokarski patrzy na nie w dramatycznym napięciu.

Wszystko wskazuje na to, że kręcąc film, Petelscy trzymali się intencji pokazania Poznania '56 (taki sam zapis jak w scenariuszu obecny jest w scenopisie ${ }^{7}$ ), zmiana zaś zaszła pomiędzy zakończeniem zdjęć a kolaudacją (podczas tej ostatniej jest już mowa o zestawieniu kroniki węgierskiej i polskiej ${ }^{8}$ ). Gdy się ogląda gotowy film, uderza nieadekwatność i emocjonalna niewspółmierność reakcji Tokarskiego na obejrzaną kronikę (reakcję tę natomiast tłumaczyłby materiał z Poznania). W filmie ostatnim materiałem, jaki Tokarski obejrzał w kinie, był ten o entuzjastycznie witanym przez Polaków zgromadzonych na placu Defilad Gomułce, który musiał być przez niego (reformistycznie nastawionego komunistę, o czym jeszcze wspomnę) przywitany jeśli nie z entuzjazmem, to przynajmniej z satysfakcja. Dlatego też późniejszy dialog z Margit jest ewidentnie nieadekwatny do obejrzanej kroniki i zbyt dramatyczny (pamiętajmy, że w kronice krwawe są wydarzenia z Węgier, z Polski zaś - pokojowe):

- Żałuję, że musiałaś na to patrzyć.

- Nie, przynajmniej zrozumiałam cały tragizm.

- Nic nie zrozumiałaś, ty nie możesz tego zrozumieć, wyście nigdy nie byli zagrożeni.

Tylko człowiek, który się dusi, wie, czym jest otwarte okno.

- Jan, po czyjej ty jesteś stronie.

- Nie wiem, nie wiem. Za mało wiem, jak jest naprawdę w kraju.

Czy jest do pomyślenia taka właśnie - pełna zagubienia, poczucia zniewolenia i goryczy - reakcja uczciwego komunisty na wiec na placu Defilad?? Pytanie retoryczne. Natomiast jak najbardziej jest ona uzasadniona, gdy pod pokazany w filmie materiał podłoży się ten, który miał być zaprezentowany - dramatyczną kronikę

7 E. i Cz. Petelscy, Kamienne tablice. Scenopis filmu na motywach powieści Wojciecha Żukrowskiego, Warszawa 1982, uj. 309-405, 412-414 (dziękuję Panu Adamowi Wyżyńskiemu za pomoc $\mathrm{w}$ zdobyciu informacji ze scenopisu w trudnym pandemicznym okresie). O tych ujęciach z wydarzeniami poznańskiego Czerwca wspomina się także w relacji z planu opublikowanej w tygodniku „Film” - [bz], Polityka i mitośc. O filmie Eny i Cžestawa Petelskich „Kamienne tablice”, „Film” 1983, nr 20, s. 7.

8 Archiwum FINA, A-344, Stenogram z posiedzenia Komisji Kolaudacyjnej Filmów Fabularnych w dniu 9 grudnia 1983 r. (Kamienne tablice), poz. 345; dalsze cytaty z kolaudacji pochodza z tego egzemplarza.

9 Takie poczucie nieadekwatności wykorzystania kroniki z wiecem na placu Defilad ujawniała na kolaudacji Wanda Jakubowska, mówiąc: „Ktoś tutaj powiedział, że film ten oddaje sprawiedliwość 
z wydarzeń w Poznaniu (na fabularną nieciagłość wskazuje także chronologia - kochankowie oglądają kronikę tuż po wspomnianych informacjach o walkach w stolicy Wielkopolski). Oczywiście, czujny polski widz - nauczony języka ezopowego - w tym kompulsywnym (dwukrotnym!) oglądaniu przez Jana węgierskiej części kroniki (za drugim razem pokazany jest tylko ten fragment, bez partii z Gomułka) mógł się dopatrzyć metaforyzowania wydarzeń poznańskich poprzez wydarzenia budapesztańskie. Mało prawdopodobne jest jednak, że była to intencja autorów filmu; pokazując po raz drugi wydarzenia węgierskie, ratowali raczej aktorską, dramatyczną reakcję Chamca, łagodzili opisywaną niewspółmierność. Gdyby bowiem chodziło tylko o podkreślenie tragizmu zmian dokonujących się w krajach socjalistycznych, materiał węgierski (tak jak w scenariuszu materiał poznański) zostałby pokazany bez warszawskiej kroniki.

Dodanie zdjęć ze słynnego wiecu z placu Defilad wygenerowało nowe, alegoryczne i ahistoryczne znaczenia. Przywołanie wątku węgierskiego w kontraście do kroniki z Gomułką posłużyło do konfrontacji dwóch metod załatwiania politycznego konfliktu w obozie państw socjalistycznych: eskalacji zakończonej wkroczeniem wojsk, w domyśle: radzieckich (przypadek Węgier 1956 r.) oraz załatwienia sprawy droga ,pokojowego współdziałania” pod przewodem partii (przypadek polskiego Października i Gomułki). W takiej sytuacji mogły pojawić się (przynajmniej u piszącego te słowa się pojawiły) skojarzenia: Październik 1956 - Grudzień 1981, Gomułka - Jaruzelski (wraz z zagrożeniem radzieckim). Warto przypomnieć, że po 1980 r. postać byłego pierwszego sekretarza - w kontrze do odsuniętego Gierka - ponownie zaczęła być oficjalnie użyteczna. „W 1981 roku Wojciech Jaruzelski odwiedził zatem Gomułkę w szpitalu, a kiedy były przywódca zmarł, co nastąpiło rok później, jego ciało wystawiono w Sejmie i pochowano z honorami państwowymi. Jeszcze w 1982 roku pojawiły się liczne inicjatywy mające na celu uhonorowanie byłego I sekretarza KC PZPR, które trwały aż do końca PRL-u. Włączyło się w to także kino" - pisał o tym zjawisku Piotr Zwierzchowski ${ }^{10}$.

Zmiana materiału archiwalnego uwspółcześnia więc polityczną wymowę filmu w stronę aktualnej ideologicznej perswazji, bo, jak oznajmiał na kolaudacji Petelski, „wiele spraw ma aktualne odniesienia i to też było naszą intencją” (s. 22). Natomiast redaktor Wieluński aluzyjnie dodawał: „Państwo Petelscy zinterpretowali w sposób współczesny te wydarzenia, o jakich pisał w powieści Pan Żukrowski i dlatego wysuwa się w filmie jego aktualność i sądzę, że od strony dramatycznej ten film brzmi ostrzegawczo" (s. 20). Potwierdzał to także przewodniczący komisji kolaudacyjnej, zamykając spotkanie: „Odniesienia do naszej współczesności są tutaj wyraźne i po-

Wiesławowi, bo została tam pokazana autentyczna kronika filmowa, ale nie bardzo widzę, ażeby była ona wpleciona w tę całą historię" - Ibidem, s. 18.

${ }_{10}$ Maszynopis przygotowywanej do druku książki o wizerunku sekretarzy partyjnych w polskim kinie autorstwa Piotra Zwierzchowskiego - dziękuję autorowi za udostępnienie opracowania. 
trzebne" (s. 24). Ciekawe, że tej wyraźnej niewspółmierności bodźca (kronika węgierska i ujęcia Gomułki) do reakcji bohatera niemal w ogóle nie dostrzegli krytycy. Jako jedyna zauważyła to recenzentka „Filmu” Elżbieta Dolińska, pisząc: „,następna dramaturgiczna kulminacja wypada w październiku, gdy Jan ogląa w kinie kronikę ze zdjęciami z Budapesztu i Władysława Gomułkę na placu Defilad. Jako Polak powinien być już wtedy spokojny, pewny, gdzie jego miejsce, ufający zmianom, już po decydującej rozmowie ze soba. A jednak teraz dopiero zachodzi w nim proces, który ostatecznie przyniesie decyzje powrotu do kraju i rezygnację z miłości”"11. Pomimo przyjęcia filmu na kolaudacji sternicy polskiej kultury nadal musieli mieć wątpliwości, czy ten fragment historii 1956 r. (Czerwiec ${ }^{12}$, węgierski i polski Październik) pokazywać na ekranie, skoro kolaudację dzieliło od premiery (22 października 1984 r.) aż 10 miesięcy.

Fabularna zmiana z Czerwca na Październik była najważniejsza, ale gdy się przyjrzeć uważniej scenariuszowi, to w kilku innych miejscach widać łagodzenie historycznej (resp. politycznej) wymowy. Zupełnie niezwykła jest - zapisana w scenariuszu - opowieść Judyty, sekretarki pracującej w ambasadzie. Opowiada ona bowiem Janowi o zesłaniu na Syberię:

Uciekłam za Bug, przed Hitlerem. Chciałam być od niego jak najdalej. I byłam, wywieźli mnie nad ujście Obi. Pamiętam do dziś te brunatne osiedla z kłód, te straszne pnie jak martwe kolumny, las obcięty na wysokości trzech metrów... Zachodziłam w głowę, kto zadawał sobie ten bezsensowny trud? A to po prostu napadało trzy metry śniegu, drwale ścinali, stojąc na nartach przy czterdziestostopniowym mrozie, od którego belki w chałupach strzelały, jakbyś w nie walił obuchem... Nie wyrabiałam normy, miałam wszy, liszaje, wrzody na twarzy od kleszczy, które kapały z liści... Ale jeszcze budziłam pożądanie. Załatwiali te sprawy na narach w łaźni, dostawałam pajdę chleba. Nie gardzisz mną? Janku, ja chciałam przeżyć. Wróciłam do Warszawy, pracowałam w prokuraturze wojskowej (s. 74).

Trudno sobie wyobrazić, aby taki fragment filmu pojawił się na ekranie po 13 grudnia, został więc już w scenopisie mocno ograniczony i odpowiednio przetworzony dla doraźnych potrzeb - ucieczka Judyty za Bug się nie udaje, ostatecznie trafia w góry Harzu, gdzie kupuje ją Niemiec „piękny jak Apollo”, a ona sama ląduje w końcu w żołnierskim burdelu. Z jej opowieści zostaje tylko prokuratura, ale już nie wojskowa.

Ocena postaw politycznych bohaterów filmu - głównie pracowników ambasady w Delhi - odbywa się z perspektywy uczciwego komunisty, rewizjonisty z okresu

11 E. Dolińska, Inkrustowana sqkatułka, „Film” 1984, nr 50, s. 9.

12 Zob. casus filmów Andrzeja Marka Drążewskiego Niepokonani i Jeszcrze czekam... o Czerwcu 1956 r.; M. Guzek, „Niepokonani” A. Marka Drażenskiego jako źródto do dziejón Października 56 [w:] Październik 1956 w literaturze i filmie, red. M. Zawodniak, P. Zwierzchowski, Bydgoszcz 2010, s. 257-259. 
Października, zgodnie z przywołanym już wcześniej sloganem: „socjalizm tak, wypaczenia nie". Z ekscytacją i akceptacją przyjmuje więc Tokarski informacje o kolejnych etapach politycznej odwilży: aresztowaniu Romkowskiego i Fejgina z X Departamentu MBP, rehabilitacji oficerów rozstrzelanych po procesie Tatara, Mossora i Kirchmayera, o usunięciu Bermana z Biura Politycznego, o VII Plenum KC PZPR, przywróceniu Gomułce praw członka partii - choć wszystkie te informacje i reakcje bohatera sa zaprezentowane $\mathrm{w}$ formule drętwej, propagandowej pogadanki. Negatywna postacią jest ambasador Banach (Janusz Kłosiński), stalinowski dzierżymorda, a na dodatek zabójca i kłamca (w wypadku prowadzonego przez niego samochodu ginie przypadkowe dziecko, do czego ambasador nie chce się przyznać, zrzucając winę na hinduskiego kierowcę); widz pod koniec filmu (jeśli do niego dotrwa) z satysfakcja przyjmuje fakt odwołania go ze stanowiska (nie da się jednak ukryć, że w tej mizerii aktorskiej, jaką jest dzieło Petelskich, grający ambasadora Janusz Kłosiński brzmi o wiele wiarygodniej niż Chamiec jako Tokarski). Jednak ani ocena zachowań ambasadora jako przedstawiciela stalinowskiego establishmentu, ani tu i ówdzie wypowiadane przez bohaterów opinie w stylu „tępaki muszą odejść” (w odniesieniu do stalinowców) nie oznaczają zachwiania wiary w sam socjalizm. W związku z tym nawet nasz światły i zatroskany bohater wypowiada (a właściwie deklamuje) zdania typu „rząd czasem musi być rewolucyjny”.

Po obejrzeniu filmu widz nie miał watpliwości, że sojusze zostały podtrzymane, socjalizm obroniony, a Zachód - potępiony. Sojusze podtrzymane, bowiem tymi, którzy potrafia prawdziwie współczuć naszemu bohaterowi z powodu bolesnych wydarzeń poznańskich, są towarzysze radziecki i węgierski. Zwłaszcza ten pierwszy okazuje empatię, gdy mówi: „Tylko za te wszystkie bezprawia i nadużycia władzy wystarczyłoby winnych pod sąd, a nie wymachiwać szabelka, świętą wojnę przeciwko socjalizmowi robić"; albo gdy - reagując na radość francuskiego korespondenta z nadmiaru wydarzeń, które musi relacjonować (jest w centrum uwagi!) - dodaje: „Widzisz Tokarski, dla was dramat, a dla innych karta w rozgrywce. Cieszy się... Szlag by go trafił".

W opisie wydarzeń na Węgrzech zawartym w kronice nie ma ani słowa o Armii Czerwonej i o tym, że czołgi, które patrolują ulice, to czołgi sowieckie. Z kolei socjalizmu najwiarygodniej bronią szeregowi pracownicy ambasady: woźny i szyfrant. Ten pierwszy gotów ponownie przelać krew za Polskę i socjalizm; drugi zaś deklaruje: „Ale ja się tam na socjalizm, wie Pan, nie obrażam, już parę ładnych lat jeżdżę po zagranicy i jedno panu powiem - wszędzie dobrze, gdzie nas nie ma. Wie pan, tylko przykro patrzeć, że w takiej chwili jak teraz ta nasza Polska niejednemu u dupy wisi”. A o krytykę Zachodu zadbał nie tylko wcześniej wspomniany radziecki towarzysz, ale także Tokarski, który w łóżku z Margit głosi filipiki na okrutny imperializm Anglików, dawnych władców Indii, dodając: „Ja jestem jak trędowaty i to co najmniej dla jeden trzeciej ludzkości, ponieważ jestem stamtąd, od czerwonych". 


\section{Erotyka}

Kamienne tablice można także uznać za melodramat, film o miłości niemożliwej przeszkodami są tu zarówno kraj pochodzenia kochanków (z różnych bloków politycznych - Margit jest Australijka, choć - dodajmy - w filmowej inscenizacji nic na to nie wskazuje), jak również stan cywilny Jana (ma żonę i dwóch synów). O melodramacie możemy jednak mówić tylko w warstwie fabularnej (w tym w patetycznych dialogach), bowiem w sferze inscenizacji i stylu wizualnego już ten melodramatyczny charakter znika, bowiem brakuje temu obrazowi pasji miłosnego uczucia, patosu miłości, dla której inne rzeczy są mało istotne. Trudno uwierzyć, że Margit i Jan sa „bytami-ku-miłości”" ${ }^{13}$. Aktorzy grają bezbarwnie, bardziej w konwencji dramatu psychologicznego niż romansu (Laura Lącz jest wycofana, Krzysztof Chamiec zaś - jako amant! - pretensjonalny w powtarzanych teatralnie słowach ,kocham cię, kocham cię”, ,jesteś, jesteś” czy „Margit, Margit”). Tylko muzyka Jerzego Maksymiuka zasługuje na pochwałę, ale już nie jej wykorzystanie przez Petelskiego, który szasta nią na prawo i lewo. Pozostało jednak kilka autonomicznych ujęć erotycznych będących wabikiem dla wyposzczonych widzów.

Kino polskie stało się w dekadzie lat 80 . bez watpienia obyczajowo bardziej liberalne niż we wcześniejszych dziesięcioleciach. Jak pisałem w innym miejscu, dekada ta odznaczała się erotyzacją polskiego kina ${ }^{14}$. Odbywała się ona w dwóch zakresach. Po pierwsze, w realizacji filmów, które można nazwać erotycznymi lub erotyzującymi, a w których pozornie chodziło o sprawy głębsze niż epatowanie golizną. Uciekano więc w formułę modernistycznej stylizacji (Widziadto, Thais, Prz̨eznaczenie, Łuk Erosa) lub prezentowano nagość w oprawie science fiction (Seksmisja). Ówczesną tendencję do ubierania filmów erotycznych/erotyzujących w szaty poważnego wywodu Juliusz Machulski skomentował w dosadny sposób: „Znam wiele filmów, gdzie były budowane całe filozoficzne konstrukcje, żeby pokazać za przeproszeniem «goła dupę»" ${ }^{15}$. Petelscy przemycali ową tylną część ciała pod pozorami rzeczonego dramatu politycznego. Po drugie - fabuły polskich filmów lat 80. inkrustowane były generalnie (bez względu na to, czy fabuła tego wymagała) odważnymi, jak na wcześniejsza praktykę, obrazami seksu (tzw. momentami). Często jednak element erotyczny nie miał żadnego fabularnego uzasadnienia i stanowił wartość samą w sobie, wartość wymienną w relacji dzieło - widz.

13 A. Madej, Mitologie i konwencje. O polskim kinie fabularnym dwudziestolecia międrywojennego, Kraków 1994, s. 33-55.

14 K. Kornacki, Naga władza. Polskie kino erotyczne (schytkowego PRL-u), „Studia Filmoznawcze” 2008 , t. 29 , s. $195-224$.

15 Ibidem, s. 211. 
Kamienne tablice Żukrowskiego w sferze prezentacji erotyki były wyjątkowo odważne:

Suknia podwinęła się, ściągnięta niecierpliwą ręką, zobaczył smukłe, śniade uda. Była pod spodem naga. Masz mnie - tchnęła mu w oczy. Pochylił się nad nią, widział jej biodra złotawe, ciemny kędzierzawy trójkąt. Z gniewną rozkoszą wdarł się, oplotła go mocno nogami, chłonęła w siebie, brała w niewolę, zaciskała gorące pęta. Czuł jej wnętrze palące i śliskie ${ }^{16}$.

W książce Zukrowskiego czytelnik mógł odnaleźć więcej takich odważnych opisów ${ }^{17}$.

Petelscy jako scenarzyści i Petelski jako reżyser (Laura Łącz wspominała, że Petelskiej nie było na planie ${ }^{18}$ ) pozbawili prezentowane w filmie sceny erotyczne dosadności, jaką można odnaleźć u Żukrowskiego. Mieli pewnie świadomość, że ten stopień pisarskiej szczerości na ekranie nie wchodził w grę i ocierałby się o pornografię. W związku z tym Petelski nastawił się na prezentowanie nagości Łącz w konwencji zbliżonej do fotograficznego aktu. Niby bohaterowie się ruszaja, niby sugerują stosunek seksualny, ale całość jest bardzo statyczna. W pamięci widza pozostaje pokazywane w planie pełnym lub ogólnym nagie ciało aktorki (czy to z przodu, czy to z tyłu w poetyckim półmroku). Jako inscenizator Petelski wyraźnie się męczy, nie wie, jak rozwiązać konflikt pomiędzy namiętnością kochanków a koniecznością ukrywania niektórych newralgicznych elementów kobiecej i męskiej anatomii. Widać to już w pierwszej odważnej scenie. Oto kamera umieszczona nad wentylatorem, filmująca z perspektywy sufitu, prezentuje kochającą się na podłodze parę. Jan ${ }^{19}$ leży na lewej połowie ciała Margit/Łącz, ta zaś podniosła prawe kolano w taki sposób, aby zakryć łono. Dubler Chamca pozoruje namiętność, a Łącz trzyma sztywno uniesione zgięte kolano i stara się nie odchylać go od pionu. Całość uderza przede wszystkim stopniem inscenizacyjnego samoograniczenia - zamiast aktu seksualnego jest walka $\mathrm{z}$ jego spontanicznością. Jest w filmie jeszcze kilka takich scen (nagi akt Łącz w scenie monsunu czy scena zbliżenia na plaży; kuriozalna jest natomiast ta scena, w której na pytanie Tokarskiego/Chamca: „Nie zostaniesz?”, Margit/Lącz odpowiada: „Jak chcesz” i bezceremonialnie, a jednocześnie bezna-

16 W. Żukrowski, Kamienne tablice, t. 1, s. 44.

17 Bardziej dosadne niż film są także niektóre zapisy scenariusza. Oto jeden z nich: „Oparła skroń o policzek, lgnęła całym ciałem. I wiedzeni jedną myślą, wtopieni w siebie, osunęli się na dywan. Wyłuskiwał ją z sukienki, widział wzniesione piersi, linie biodra i trójkątne zaciemnienie między udami. Podsunął się na kolanach, wsparł dłonie w jej dłoniach, miał ją tuż. Przymknęła oczy, podciagnęła kolana i rozwierała je ruchem motylim, a w tym bezwstydnym pragnieniu oddania jawi się piękno, które aż dławi" (s. 57).

18 D. Kułakowska, Jak by to naprawde na planie filmu Kamienne tablice (rozmowa z. Laura Lacz, i Kryysztofem Chamcem), , Tele Świat” 1999, nr 15; zob. także wypowiedź Laury Łącz przed projekcją filmu Kamienne tablice w kanale Kino Polska, 1 stycznia 2005 r.

19 Odtwarzany w tym momencie przez dublera. 
miętnie ściaga majtki). „Umówmy się - wspominała Łącz - pan Czesław Petelski nie był specjalistą od romansów. Może szkoda, że podczas zdjęć nie pracowała jego żona, pani Ewa"20.

Watek romansowo-erotyczny - „drewniany” w inscenizacji (tak samo zreszta jak cały film, utrzymany w anachronicznym stylu reżyserii), z niezrozumiałą obsada Krzysztofa Chamca w roli kochanka (równie wiarygodnego, jak w roli przejętego, uczciwego komunisty ${ }^{21}$ ), z fatalnie prowadzoną parą aktorów w scenach lirycznych/ miłosnych - mógł mimo to przykuwać uwagę widzów lat 80. odważnymi wówczas scenami miłosnymi, nawet jeśli reżyserowanymi bez psychologicznego zrozumienia miłości, na zasadach cielesnej ekspozycji. Nie przykuł jej jednak na tyle, by rozbić box office (zaledwie ćwierć miliona widzów) i nie przynieść strat ${ }^{22}$.

Pozostańmy jeszcze na moment w kręgu romansowych rozważań. Dociekliwi widzowie mogliby zadać sobie pytanie o tytuł: „dlaczego kamienne tablice?”; „o jakie tablice chodzi?’”. Ci, którzy znaja pierwowzór literacki, nie mieliby problemów z odpowiedzią na to pytanie, ale widzowie już tak. Informacja, że chodzi o tablice z dziesięciorgiem przykazań, pojawiała się jeszcze w scenariuszu. Odpoczywając po spełnieniu, Tokarski wdaje się w rozmowę z Margit, podczas której dzieli się swoimi wątpliwościami co do przyszłości ich związku, w tym mówi o moralnym dylemacie związanym z potencjalnym rozwodem.

- Orzeczenie sądu jest tylko formalnym rozwiązaniem małżeństwa, ja jestem katolikiem, dla nas nie ma zwolnienia z przysięgi, gdy na świadka wezwaliśmy Boga.

- To dla ciebie aż takie ważne? - w zdumieniu cofnęła dłoń.

- Przykazanie wyryte na kamiennych tablicach...

- Ja też jestem chrześcijanką, jednak nie rozumiem twoich skrupułów.

- Przysięgałem: „i nie opuszczę cię aż do śmierci”. Tylko śmierć przecina małżeństwo (s. 98).

Ten fragment, którego ostatecznie brak w wersji ekranowej, został z pewnościa nakręcony, skoro kolaudanci wnieśli postulat jego usunięcia ${ }^{23}$. Zrezygnowano także

${ }_{20}$ D. Kułakowska, Jak byto naprawde...

21 Chamiec miał pierwotnie grać ambasadora; zob. W. Cybulski, Kamienne tablice, „Dziennik Polski” 1984, nr 301. Generalnie ekipa miała kłopot z obsadą: „Głównym problemem, jaki w tym okresie wystapił, to niesławny «bojkot» aktorów, co nie ułatwiło życia realizatorom filmu”; Archiwum Dokumentacji Osobowej i Płacowej w Milanówku, zespół archiwalny „Zespoły Polskich Producentów Filmowych", 468, Sprawozdanie organizacyjno-ekonomiczne z realizacji filmu fabularnego Kamienne tablice, k. 13.

22 Archiwum Dokumentacji Osobowej i Płacowej w Milanówku, zespół archiwalny „Zespoły Polskich Producentów Filmowych”, 373, Kontrola NIK 1985-1986, t. 1, k. 112-113, 120.

23 „Mnie się wydaje, że wszystkie sprawy polityczne zostały bardzo dobrze pokazane, ale miałbym prośbę, ażeby wyrzucić te wyznania, które dotyczą motywacji religijnej, bo nie tylko o to tutaj chodzi, ale chodzi również o stosunek do samego siebie, do własnych przekonań, do 
(już na etapie scenopisu) z obecnej w scenariuszu rozbudowanej sceny poznania starego polskiego księdza-zakonnika, którego bohaterowie spotykają w dzień Bożego Narodzenia (Margit zachwyca się pasterką, mówiąc „To jest piękne, wspaniałe...”). W scenie tej ksiądz dopytuje Tokarskiego o to, kim jest Margit („Pan jest katolikiem, skoro pan tu przyszedł"), pogłębiając jego moralne wątpliwości. Wszystkie te religijne tropy ostatecznie zniknęły z filmu - można się domyślać, że z powodu ówczesnego politycznego kontekstu i negatywnego stosunku do Kościoła katolickiego w stanie wojennym. Redukcje spowodowały jednak, że tytuł zawisł w próżni, a motywacje porzucenia Margit stały się dużo bardziej wątłe.

W kontekście opisanej powyżej eliminacji scen odwołujących się do religii dopowiedzmy: $\mathrm{w}$ momencie pisania scenariusza Petelscy gotowi byli na odważne adekwatne do czasów solidarnościowej rewolucji - wątki tematyczne, takie jak prezentacja krwawych wydarzeń Czerwca '56, słowa Judyty o zesłaniu na Syberię czy obecność pozytywnie waloryzowanego doświadczenia katolickiego, tak ważnego dla genealogii i społecznego zaplecza Solidarności (ale także dla literackiego pierwowzoru). Po wprowadzeniu stanu wojennego usunęli te wątki, dostosowując film do ideologicznych wymogów.

\section{Egzotyka}

W obszernej, dwutomowej powieści Żukrowskiego opis spraw hinduskich zajmuje bardzo dużo miejsca. Zrozumiałe było, że nawet w filmie dwuseryjnym (ostatecznie film Petelskich trwa 135 min, przy czym pokazywany był jako jedna całość) konieczne będą radykalne cięcia. Minimalizowanie tego wątku była zresztą świadomą decyzją Petelskich ${ }^{24}$. Niemniej, porównanie scenariusza z gotowym filmem wskazuje na coraz dalej idącą redukcję hinduskiego kontekstu - z powodów ekonomicznych. Jeszcze w scenariuszu obraz Indii jest bardziej bogaty i precyzyjny w opisie konkretnych zjawisk kulturowych AD 1956 niż w filmie. Już scenariuszowy prolog (na którym miały pojawić się napisy początkowe) znamionuje pragnienie etnograficznego opisu. Przejażdżka Tokarskiego i Margit po Starym Delhi miała być okazją do pokazania materialnego statusu mieszkańców tego miasta/dzielnicy i jej obyczajów. Pozwolę sobie na nieco dłuższy cytat ze scenariusza:

Niskie lepianki ciasno obstąpiły drogę, na dachach krytych płatami pordzewiałej blachy dreptały gołębie. Przy kopcących ogniskach ukucnęły kobiety, smażąc placki na patelniach, nagie dzieci wielkimi oczami wodziły za buczącymi autami (...) Otoczył ich tłum,

własnego poczucia moralności" - tymi słowami Wojciech Żukrowski sprzeciwiał się na kolaudacji motywacji działań bohatera, którego w powieści sam stworzył (s. 12).

24 „Zdecydowaliśmy się na eliminację pewnych wątków i wyeliminowane zostały w dużej mierze wątki indyjskie, z czym autor [powieści] się zgodził" (kolaudacja, s. 22). 
pokrzykiwali wędrowni fryzjerzy, czyściciele uszu, sprzedawcy jarzynowej zupy i wydrwigrosze z małpkami. Dławiąc klakson, Jan z trudem rył sobie droge w ciżbie, odsuwali się niechętnie, zaglądali natarczywie do wnętrza, stukali palcami po szybach. Niespodziewanie drogę zastąpiła im krowa. Różańce korali chrzęściły wokół pomarszczonej szyi zwierzęcia, pierścień ze szkiełkiem zatknięty na rogu skrzył się zielonkawo. Poczciwym, zaślinionym pyskiem wjechała na stragan z jarzynami i wyłuskiwała marchew. Nikt jej nie odpędzał. Nagle się rozkraczyła, uniosła ogon i obficie oddała mocz. Jakaś stara kobieta w szafirowym sari złapała strugę w stulone dłonie i nabożnie przemyła oczy towarzyszącej jej dziewczynce (s. 2-3).

Dalej, na kolejnych dwóch stronach czytamy jeszcze o burdelach w Starym Delhi oraz pogrzebie nad Jamuna. W planowanym prologu wybrzmiałby więc etnograficzny konkret i detal kraju o radykalnie odmiennej kulturze i obyczaju. W scenariuszu takich partii jest więcej, głównie w pierwszej jego części, zanim film podąży w kierunku polityczno-historycznej i miłosnej puenty. Jest więc scena, gdy hindusi ze zdziwieniem przyglądają się, jak Margit i Jan jedzą, posługując się sztućcami, później podobna w znaczeniach, gdy przedstawiciel Cejlonu je posiłek rękami, dziwiąc się, że można nożem i widelcem (co przypomina mu operację ginekologiczną). Podczas kongresu ku czci Tagore mowa jest o konflikcie pomiędzy Bengalczykami a Tamilami o spuściznę po pisarzu. W końcowych partiach scenariusza, w których kochankowie spędzają urlop w Koczin i niebezpiecznie wypływają łodzią w morze, jeden z Hindusów uświadamia im, że nie mogliby liczyć na pomoc ze strony miejscowych, bowiem nie chcą oni ingerować w sprawy pomiędzy morzem a topielcem (by później nie upomniało się ono po swoje i nie zabrało członka rodziny osoby, która tego topielca ratowała). Oprócz tego jest w scenariuszu jeszcze wiele wątków etnograficznych podanych czy to w dialogach, czy w opisie scenerii.

Jak łatwo zauważyć, precyzyjnie zaplanowana sekwencja prologu wymagałaby dokładnej inscenizacji (wykorzystania miejscowego pleneru i aktorów, nawet jeśli mieliby to być naturszczycy). Taki pasaż byłby dużym wyzwaniem produkcyjnym. Tymczasem, jak można wnosić ze sprawozdania produkcyjnego, możliwość realizacji filmu w Indiach była ekonomicznym wyzwaniem. „Aby zrealizować tak wielkie i trudne przedsięwzięcie, warunkiem było znalezienie odpowiedniego sponsora zagranicznego (hinduskiego), który pomógłby zorganizować i sfinansować zdjęcia w Indiach. Takim kontrahentem okazała się Indyjsko-Polska Izba Handlowo-Przemysłowa, dla której w zamian za pomoc w realizacji filmu zobowiązano się wykonać film promocyjny na taśmie $16 \mathrm{~mm}$, o długości $20 \mathrm{~min}$. Koszt filmu promocyjnego jest częścią składową filmu Kamienne tablice" ${ }^{25}$. Dzięki temu wsparciu kilkunastoosobowa ekipa mogła zrealizować zdjęcia plenerowe w Indiach.

25 Archiwum Dokumentacji Osobowej i Płacowej w Milanówku, zespół archiwalny „Zespoły Polskich Producentów Filmowych", 468, Sprawozdanie..., k. 13. 
Faktem jest jednak, że wielu fabularnych (resp. inscenizacyjnych) zamierzeń nie udało się przenieść na ekran w kształcie zapisanym w scenariuszu. Dotyczy to zwłaszcza prologu, który ze szczegółowo zaplanowanej sekwencji zmienia się w pasaż złożony z przypadkowych zdjęć ulic Delhi (inna sprawa, że oglądając ulice filmowane w roku 1983, można uwierzyć w akcję dziejącą się w 1956 - prezentowane na ekranie samochody okres świetności miały już dawno za soba). Takich powierzchownych pasaży w formule folderowych impresji i pocztówek jest w tym filmie dużo. Powtarzają się wielokrotnie sceny jazdy Jana i Margit samochodem oraz filmowanych z tej perspektywy drogi i pobocza - pokazywane jest to, co się nawinie kamerze (skaczące przy drodze małpy, wielbłądy itp.). To formuła traweloga bez komentarza, perspektywa powierzchownego turysty. Tak jest też w sekwencji uroczystej defilady ${ }^{26}$, której nie ma w scenariuszu i którą sfilmowano już na miejscu (na zasadzie znaleziska); sekwencji, która trwa ponad 3 minuty (!) i jest dramaturgicznym ciałem obcym. Podobna była geneza wielu ze wspomnianych pasaży - jakby ktoś połączył film fabularny z turystyczno-krajoznawczym. Jedynym, co spina te partie z fabuła, jest obecność patrzących na to wszystko kochanków wątła fabularna motywacja. Jak pisał z przekąsem jeden z krytyków: „Skoro Indie, to wiadomo parada słoni i Sikhów, taka konkurencja dla Klubu sześsiu kontynentón i ekip Interpressu"27.

Tylko raz mocniej związano egzotyczną lokację z melodramatyczną intryga. Chodzi o sekwencję w opuszczonym mieście Fathepur Sikri (dziś na przedmieściach Agry). Tę partię filmu zapisano już w scenariuszu i potem dość konsekwentnie zainscenizowano. Tokarski wchodzi tutaj w rolę (protekcjonalnego) przewodnika wykorzystującego swą wiedzę do manipulowania reakcjami Margit. Znając dobrze to miejsce, reżyseruje jej reakcje, bawi się jej przestrachem (gdy starzec skacze do wody), jej niewiedzą (gdy opowiada legendę wyjaśniającą opuszczenie miasta, gdy informuje o wieży samobójczyń lub ostrzega przed dotykaniem kolorowych sznureczków, które są formą błagań o dziecko). Ta partia jest funkcjonalna, wykracza poza trawelog, głębiej penetruje lokalny kontekst kulturowy (Jan jest tutaj kompetentnym przewodnikiem ${ }^{28}$ ), a jednocześnie splata się z melodramatyczną fabułą (Margit wystraszy się później, że jest w ciąży, jakby dotknięcie kolorowych sznureczków rzeczywiście przyniosło niezamierzony efekt; a siedząc na szczycie wieży, będzie wspominać własne samobójcze plany). Pozostałe hinduskie tropy nie wykroczą poza fabularne wstawki, jak ta opisowa (ale znacznie skrócona) scena kongresu ku

26 Trudno ustalić, z jakiej okazji - rozmach wydarzenia wskazywałby na defiladę z okazji Dnia Niepodległości Indii (15 sierpnia), ale w tym czasie - jeśli wierzyć Sprawozdaniu organizacyjno-ekonomicznemu - nie kręcono zdjęć w Indiach.

27 Perpedes, Kamienna widokówka, „Dziennik Zachodni” 1984, nr 271.

28 To znaczy sprawia takie wrażenie - o prawdziwych powodach opuszczenia Umarłego Miasta zob. S. Shekhar Sinha, The mystique of Fatehpur Sikri, https://frontline.thehindu.com/arts-and-culture/the-mystique-of-fatehpur-sikri/article8755640.ece (dostęp: 14.03.2021). 
czci Tagore (na zasadzie: radca kulturalny ambasady ma w końcu jakieś obowiązki) czy sugerowanie w dialogach politycznego tła (informacja o wspólnej deklaracji Nehru, Nassera i Tito).

W największym stopniu komentarzem do lokalnych tradycji jest wątek wypadku ambasadora, kierowcy ambasady Kriszana i jego żon. Ambasador Banach, jak wspominałem, prowadząc auto, zabił świętą krowę i pilnujące ją dziecko; skłonił Kriszana, by wzią winę na siebie, a potem bezdusznie pozbył się go z ambasady; rychło potem Kriszan - zmuszony do utrzymania siebie i żony niebezpieczna jazdą na motocyklu w beczce śmierci - zginął w wypadku. Wątek ten funkcjonuje przede wszystkim jako oskarżycielska identyfikacja ambasadora, stalinowskiego cadyka, ale uzmysławia także znany status krów w społeczeństwie hinduskim (w scenariuszu wcześniej już zasugerowany w opisywanym prologu). Również osobiste życie Kriszana uwypukla odmienność kultur i obyczaju - kierowca ambasady ze stoickim spokojem słucha jęków swojej pierwszej żony cierpiącej na guz (jak można się domyślać, nieuleczalny, niedługo potem bowiem kobieta umiera) i ze szczerością mówi:

- Ona ma guz, ale jakby go wyciąć, nie będzie już mogła rodzić. To po co mi taka żona. Tokarski: Zrozum, ona się męczy.

Kriszan: A ja nie? Już drugi dzień nie daje chwili odetchnąć. Niech już zemrze albo niech wyzdrowieje. Bo tak to tylko zawada, ani do życia, ani do roboty. Zostaw sab, co ma być, to będzie.

Postawa Kriszana wzbudza oburzenie woźnego ambasady („Kriszan się tylko śmieje i szczerzy zęby. To niedobry człowiek, panie radco"), także Tokarski wydaje się nią wzburzony. To typowe spojrzenia człowieka Okcydentu, próbującego interpretować rzeczywistość według zachodnich wartości. Tymczasem nawet cierpiąca akceptuje swoje przeznaczenie, tłumacząc je religijnie - nie chce być operowana (jak mówi Michaś, syn jednego z pracowników ambasady: „Ona tam [w szpitalu - K.K.] była, wujku, i mieli ją kroić, ale ona nie chce, żeby ja palili po trochu, ona woli, żeby ja od razu cała. Bo gdzie potem szukać siebie do następnych narodzin”), potem sugeruje Kriszanowi, by za kolejną żonę wziął jej siostrę. To okrutna dla człowieka Zachodu, ale dosadna lekcja odmienności religijnych i społecznych, w tym - roli i statusu kobiety w kastowym społeczeństwie hinduskim ${ }^{29}$.

Owo zdziwienie, a nawet oburzenie postawą Kriszana wpisuje się w kulturową aksjologię filmu - jest on realizowany z perspektywy Obcego, który nie wchodzi

29 Choć, dodajmy, w kontekście takich zjawisk, jak sytuacja kobiet w Indiach, rok 1983 (w którym realizowano film) nie różnił się bardzo od sytuacji sprzed ćwierćwiecza, do dziś bowiem kobiety hinduskie egzystują w silnie patriarchalnej strukturze społecznej; zob. A. Staniszewska, Status spoteczno-polityczny kobiety w Indiach na przetomie XX $i$ XXI wieku - konflikt tradycji i prawa, „Świat Idei i Polityki” 2013, t. 12, s. 42-53. 
w bliższą relację z mieszkańcami Indii, nie próbuje ich tak naprawdę poznać i zrozumieć, jest hierarchicznie usytuowany wyżej niż oni jako przypadkowy turysta lub pracodawca (hinduscy służący spełniają zachcianki swego pana; Tokarski jest wobec nich chłodno uprzejmy i protekcjonalny, ale jednocześnie nie interesuje się ich życiem). Indyjski żywioł, tak mocno obecny i opisany w powieści (w tym galeria Hindusów z różnych kast i o różnym statusie społecznym i materialnym, bohaterów, którzy są „u siebie” i to do nich musi się dopasować książkowy bohater), wzmacniał równowagę obu światów, konfrontował je z sobą; ważną w powieści figurą narracyjną było patrzenie - często to Hindusi spoglądali „szeroko otwartymi oczami" na świat dyplomatów ${ }^{30}$. Ślady autonomii tego świata obecne były jeszcze w scenariuszu, ot, choćby we wspomnianym prologu, ale także w scenie, w której członkowie rodziny Preima (służącego Tokarskiego) przyglądają się z zaborczą ciekawością posiłkowi Jana i Margit - jak kulturowemu spektaklowi; w ten sposób na moment to oni stawali się „władcami spojrzenia” (wprawiając zresztą Jana i Margit w zakłopotanie). W filmie nawet tej sceny już nie ma, co sprawia, że powierzchowność spojrzenia i paternalizm relacji wobec Indii i jej obywateli jeszcze mocniej wzrasta. „Z filmu wyparowała cała gorącość klimatu Indii - pisał Władysław Cybulski. - Bohater skazany został na ustawiczne przejazdy samochodem, jak turysta, a zredukowanie do minimum kontaktów ze środowiskiem hinduskim odjęło tak ważny moment fascynacji obcym otoczeniem, a zarazem poczucie izolacji wobec odrębności narodowych i społecznych w kulturze i systemie wartości”31.

Krytycy obeszli się z filmem bezpardonowo. Tylko obrazki, „Kamienne tablice” dtugie i nudne, Krach operacji „Kamienne tablice”, Miłość i polityka czyli banał, Indyjska porazka, Strzaskane tablice, Stracone szanse, Chińskie cienie, Laureat złamanego grosza, Kamienna widokówka, Kamienne kržesło, Siermię̇ne Khadżuraho - tytuły recenzji nie pozostawiały wątpliwości co do rozmiarów artystycznej klęski. Wytykano wszystkie możliwe błędy - scenariuszowe (autonomia wspomnianych trzech wątków), dotyczące obsady (zwłaszcza pary głównych aktorów), siermiężnej inscenizacji i folderowego potraktowania Indii.

Po tej porażce Petelscy nie zrealizowali już żadnego filmu „z ambicjami” (choćby politycznymi). Dwa ostatnie obrazy Kim jest ten człowiek? (1985) oraz Gorzka miłość (1989) utrzymane były w formule kina rozrywkowego (z licznymi scenami nagości) z historia polityczną w bardzo dalekim tle. Gdy ogląda się trzy ostatnie filmy Petelskich, nie sposób uciec od gorzkiej refleksji - zaczęli swoją twórczość od obnażania wroga klasowego (Trzy opowieści z 1953 r.) ${ }^{32}$, a skończyli na obnażaniu kobiet.

30 Zob. E. Bartos, Podgladanie: o „Kamiennych tablicach” Wojciecha Żukrowskiego [w:] Literatura popularna, t. 1, Dyskursy wielorakie, red. E. Bartos, M. Tomczok, Katowice 2013, s. 429-442.

31 W. Cybulski, Kamienne tablice...

32 Zob. K. Kornacki, Ewa i Czesław Petelscy - w krainie PRL-u [w:] Autorsy kina polskiego, t. 2, red. G. Stachówna, B. Zmudziński, Kraków 2007, s. 43-77. 


\section{SUMMARY}

\section{POLITICS, EROTICISM, EXOTICISM. ON THE STONE TABLETS BY PETELSCY}

The article describes Kamienne tablice (Stone Tablets), one of the last movies directed by Ewa and Czesław Petelscy, the once-known director's tandem. In the 1980s, after the introduction of martial law, they remained faithful to the communist authority, so they could realize high-budget films. That is why the film Kamienne tablice was taking place in India in 1956, and some of the pictures were just filmed in India. Therefore, the movie was very poor and its three threads - political, erotic, and exotic - do not make up the whole. Political thread has been considerably softened compared to the initial plans and tailored to ideological needs. Petelski also failed to create a credible melodrama (the only thing that was supposed to attract viewers was erotic scenes, but they were poorly staged), and India is shown superficially, like in travelogue, from the perspective of a stranger. 